\title{
Isolation and characterization of eight novel microsatellite markers in Acanthopagrus schlegelii
}

\author{
X.Q. Mao ${ }^{1,2}$, Z.B. Li ${ }^{1,2}$, Y. Yuan ${ }^{1,2}$, Y.F. Ning ${ }^{1,2}$, J.B. Shangguan ${ }^{1,2}$, \\ Y.S. Huang ${ }^{1,2}$, M Yang ${ }^{1,2}$ and B.B. Li $^{1,2}$ \\ ${ }^{1}$ Fisheries College, Jimei University, Xiamen, China \\ ${ }^{2}$ Fujian Provincial Key Laboratory of Marine Fishery Resources and \\ Eco-environment, Xiamen, China \\ Corresponding author: Z.B. Li \\ E-mail: lizhongbao@jmu.edu.cn
}

Genet. Mol. Res. 15 (2): gmr.15027902

Received October 26, 2015

Accepted March 11, 2016

Published June 17, 2016

DOI http://dx.doi.org/10.4238/gmr.15027902

\begin{abstract}
Acanthopagrus schlegelii is a warm temperate demersal fish, which inhabits the sediment substrate or rocky reefs in shallow seas. As this fish is a nutritionally endowed species with good palatability, it is a highly valuable commercial species for aquaculture and has a long historical standing in Western Pacific countries. Because the population of this fish is currently declining in China, studies and measures aimed at addressing this decline are needed. In this study, eight microsatellite markers were screened from 30 wild A. schlegelii fishes through the FIASCO method, whereby sequences containing repeats were obtained from amplified fragment length polymorphisms. The allelic number ranged from 3 to 5, with a mean number of 3.625. The average observed heterozygosity was 0.6290 , ranging from 0.3214 to 0.8966 , while the expected heterozygosity was 0.5435 , ranging from 0.3452 to 0.6721 . The value for polymorphism information content ranged from 0.313 to 0.666 . These results show this population has moderate genetic
\end{abstract}


variation and low genetic diversity. These novel polymorphic loci will be useful for future genetic studies of $A$. schlegelii.

Key words: Acanthopagrus schlegelii; Genetic markers; Microsatellites; FIASCO

\section{INTRODUCTION}

Acanthopagrus schlegelii, also known as black seabream or Acanthopagrus schlegeli, belongs to the family Sparidae. It is a common species in the countries of East Asia and Viet Nam (Lindberg and Krasyukova, 1969), and usually lives in brackish water or on rocky reefs. In those countries, $A$. schlegelii is a traditional agriculture fish, especially in China and Japan (Fushimi, 2001). As this fish is noted for its good taste and nutritional content, a radical decrease in its population occurred at the end of the 1970s in Japan, and its population is currently declining in China. To recover the population of $A$. schlegelii, a variety of enhancement and release programs have been adopted in Japan (Kitada and Kishino, 2006) and in some areas of China. Furthermore, improvements in living conditions results in an increased volume of domestic sewage and trade effluent being released into the shallow water, which has a negative effect on the population of this fish (Shahidul Islam and Tanaka, 2004).

Microsatellite DNA markers are also named simple sequence repeats (SSRs) and short tandem repeats (STRs), since the unit of repetition is only 2-6 nucleotides long (Field and Wills, 1996). Compared to other genetic markers, SRTs have an advantage over morphological markers due to their ability to reveal co-dominantly inherited multi-allelic products of loci. Furthermore, they are not influenced by epistatic effects or impacted by the environment (Jarne and Lagoda, 1996). Because STRs are useful tools for use in population genetics research, they have been used to study the genetic structure of populations (Dou et al., 2015; Luo et al., 2015), and as an effective tool for mapping programs, population biologists, and paternity tests. STRs have been used to study the genetics of $A$. schlegelii (Gonzalez et al., 2008; Jeong et al., 2007; Yang et al., 2014). Here, eight novel microsatellite markers are presented, which could provide a powerful tool for the study of population genetics in A. schlegelii.

\section{MATERIAL AND METHODS}

\section{Fish sample collection and DNA extraction}

Thirty A. schlegelii individuals were collected from the stock enhancement program in Zhangpu, China, and genomic DNA from the musculature was extracted using a standard proteinase $\mathrm{K} /$ phenol-chloroform extraction protocol (Sambrook and Russell, 2000). Electrophoresis, on a $1 \%$ agarose and under an ultraviolet spectrophotometer, was used to estimate the concentration of DNA in each sample. The samples were then stored at $-20^{\circ} \mathrm{C}$ until use.

\section{Microsatellite-enriched library construction}

Microsatellites of $A$. schlegelii were enriched following the technique, which is using the fast isolation by amplified fragment length polymorphism (AFLP) of sequences containing repeats (FIASCO) protocol (Zane et al. 2002). The restriction enzyme FastDigest 
MseI (Fermentas, Vilnius, Lithuania) was first used to cut the DNA $(100 \mathrm{ng} / \mu \mathrm{L})$ at $65^{\circ} \mathrm{C}$ for $10 \mathrm{~min}$, and then products were bound to $\mathrm{MseI}$ adapters by T4 DNA ligase at $22^{\circ} \mathrm{C}$ for $12 \mathrm{~h}$ (Fermentas) (adapter A: 5'-ACGATGAGTCCTGAG-3' and adapter B: 5'-TACTCAGG ACTCAT-3'). Subsequently, the concatenated DNA samples were mixed with the bio-labeled oligonucleotide probes $(\mathrm{CT})_{15}$ and $(\mathrm{GT})_{15}$ following denaturation and reacted at $61^{\circ} \mathrm{C}$ for 1 $\mathrm{h}$ to ensure that the linker-ligated fragments were captured by streptavidin-coated magnetic beads (Promega, Madison, WI, USA). The enriched DNA sequence repeats were amplified by polymerase chain reaction (PCR) with the MseI primer. Afterwards, PCR products were pieced together with the PMD ${ }^{19}-\mathrm{T}$ vector (TaKaRa, Shiga, Japan) at $16^{\circ} \mathrm{C}$ for $12 \mathrm{~h}$. After vector DNA samples were transformed into one-shot chemically competent Escherichia coli DH5 $\alpha$ cells (Tiangen, Beijing, China), and the cells were incubated at $37^{\circ} \mathrm{C}$ for $1-2 \mathrm{~h}$ and then coating the cells on the Luria-Bertani agar plates for $12-16 \mathrm{~h}$. The results of recombination were verified by PCR amplification with the M13 primer and 1\% agarose gel electrophoresis, to allow subsequent sequence measurements to be made.

\section{Primer design and polymorphism test}

After sequencing, polymorphic primers were designed on the basis of STRs via Primer Premier 5.0 software (Clarke and Gorley, 2001). Thirty genomic DNA samples were used to confirm the conditions for each primer pair. The total volume of the reaction mix for PCR was $10 \mu \mathrm{L}$, and cycling parameters were set according to the following conditions: a) $94^{\circ} \mathrm{C}$ for 10 min to ensure the DNA was denatured; b) 28-32 cycles for PCR amplification acted as $94^{\circ} \mathrm{C}$ for $40 \mathrm{~s}$, annealing temperature (Table 1) for $40 \mathrm{~s}, 60 \mathrm{~s}$ at $72^{\circ} \mathrm{C}$, for extension; c) $72^{\circ} \mathrm{C}$ for $10 \mathrm{~min}$ (Ning et al., 2015). Finally, polymorphism was acknowledged by the Sequi-Gen Sequencing Cell machine (Bio-Rad, Hercules, CA, USA) using 6\% denaturing polyacrylamide gels and, ultimately, makes it visible through the silver staining.

\begin{tabular}{|c|c|c|c|c|c|c|c|c|c|}
\hline GenBank accession No. & Locus ID & $\begin{array}{l}\text { Primer sequences }\left(5^{\prime}-3^{\prime}\right) \\
\end{array}$ & Repeat motif & Allele size (bp) & $\mathrm{Ta}\left({ }^{\circ} \mathrm{C}\right)$ & $N_{\mathrm{A}}$ & PIC & $H_{0}$ & $H_{\mathrm{E}}$ \\
\hline \multirow[t]{2}{*}{ KT898193 } & \multirow[t]{2}{*}{ HJD-4 } & TGTTGAAGGTGTGGAGGTG & \multirow[t]{2}{*}{$(\mathrm{GAG})_{8}$} & \multirow[t]{2}{*}{$220-230$} & \multirow[t]{2}{*}{61.2} & \multirow[t]{2}{*}{3} & \multirow[t]{2}{*}{0.440} & \multirow[t]{2}{*}{0.6667} & \multirow[t]{2}{*}{0.5034} \\
\hline & & GAATCAGCAGGAGAGGAAAC & & & & & & & \\
\hline \multirow[t]{2}{*}{ KT898194 } & \multirow[t]{2}{*}{ HJD-5 } & CACGAAGGCAGGAAAGAT & \multirow[t]{2}{*}{$(\mathrm{GGA})_{8}$} & \multirow[t]{2}{*}{$330-360$} & \multirow[t]{2}{*}{62.8} & \multirow[t]{2}{*}{4} & \multirow[t]{2}{*}{0.502} & \multirow[t]{2}{*}{0.6071} & \multirow[t]{2}{*}{0.4825} \\
\hline & & TTACTACGCTCCCACCAAG & & & & & & & \\
\hline \multirow[t]{2}{*}{ KT898195 } & \multirow[t]{2}{*}{ HJD-34 } & AACACTCAGGGTGAACTGGG & \multirow[t]{2}{*}{$(\mathrm{AGC})_{3}(\mathrm{GT})_{4}$} & \multirow[t]{2}{*}{$240-280$} & \multirow[t]{2}{*}{62.8} & \multirow[t]{2}{*}{3} & \multirow[t]{2}{*}{0.460} & \multirow[t]{2}{*}{0.7000} & \multirow[t]{2}{*}{0.5237} \\
\hline & & CACACACACGCTGCTGCTAT & & & & & & & \\
\hline \multirow[t]{2}{*}{ KT898196 } & \multirow[t]{2}{*}{ HJD-73 } & GCTTCATGTTTCTCGCCCTG & \multirow[t]{2}{*}{$(\mathrm{GGT})_{4}$} & \multirow[t]{2}{*}{$210-250$} & \multirow[t]{2}{*}{62.8} & \multirow[t]{2}{*}{4} & \multirow[t]{2}{*}{0.630} & \multirow[t]{2}{*}{0.8966} & \multirow[t]{2}{*}{0.6721} \\
\hline & & ATATCTTGCGTCACCAGTCG & & & & & & & \\
\hline KT898197 & HJD-97 & ATAGGTGGATGAACAGGG & $(\mathrm{CT})_{38}$ & $180-200$ & 45.4 & 3 & 0.313 & 0.4000 & 0.3452 \\
\hline & & AGAGTGATGAGGGCAGAT & & & & & & & \\
\hline KT898198 & HJD-118 & GGACGACTTTAGGGACTGG & $(\mathrm{AC})_{20}$ & $180-200$ & 48.5 & 3 & 0.482 & 0.3214 & 0.5253 \\
\hline & & AGAGCAGAATGGAATGGG & & & & & & & \\
\hline KT898199 & HJD-120 & $\begin{array}{l}\text { GATGTATTTCTCCTGTCTGCC } \\
\end{array}$ & $(\mathrm{GA})_{5 \mathrm{~N}} \mathrm{~N}(\mathrm{GT})_{6} \mathrm{~N}(\mathrm{GT})_{11}$ & $190-210$ & 64.0 & 4 & 0.666 & 0.6400 & 0.6392 \\
\hline & & TCTGTCTCTGTTTCTCCCTCTC & & & & & & & \\
\hline KT898200 & HJD-157 & GCTCTCCTTGCTTCCACTC & $(\mathrm{GT})_{19}$ & $190-220$ & 63.0 & 5 & 0.595 & 0.8000 & 0.6565 \\
\hline & & ATGACGAAGAAGAGGACGAT & & & & & & & \\
\hline
\end{tabular}

$\mathrm{Ta}=$ annealing temperature; $N_{\mathrm{A}}=$ number of polymorphic alleles per locus; $\mathrm{PIC}=$ polymorphism information content; $H_{\mathrm{O}}=$ observed heterozygosity; $H_{\mathrm{E}}=$ expected heterozygosity.

\section{Data analysis}

Allelic information was obtained by referring to the 10-bp DNA ladder 
(Fermentas); additionally, the software POPGEN (version 1.32) was applied to estimate allelic diversity and to test for zygotic equilibrium (Hardy-Weinberg), linkage disequilibrium (LD), observed heterozygosities $\left(H_{\mathrm{O}}\right)$ and expected heterozygosities $\left(H_{\mathrm{E}}\right)$; and polymorphic information content (PIC) was obtained by CERVUS 3.0 software (version 3.0).

\section{RESULTS}

In this study, 30 specimens were used to investigate polymorphisms of $A$. schlegelii. The eight polymorphic loci are characterized in Table 1. MICRO-CHECKER was used to check for errors (Van Oosterhout et al., 2004). All loci conformed to Hardy-Weinberg expectations $(\mathrm{P}>0.005)$. The allelic number (NA) varied from 3 to 5 (HJD-157) for each locus, while the allelic size distribution ranged from 180 (HJD-97) to 360 (HJD-5) bp. The PIC value ranged from 0.313 to 0.666 , and four of the eight polymorphic loci were shown to be moderately polymorphic $(0.25<$ PIC $<0.5)$, while the rest were considered to be highly polymorphic (PIC > 0.5) (Botstein et al., 1980). Furthermore, the observed heterozygosities $\left(H_{\mathrm{O}}\right)$ and expected heterozygosities $\left(H_{\mathrm{E}}\right)$ were in the range 0.3214-0.8966 and $0.3452-0.6721$, respectively.

\section{DISCUSSION}

A total of 71 clones were randomly selected for sequencing among all 168 positive clones tested by M13 primers, and up to 60 of the sequenced DNA clones were found to contain STRs. These data show that FIASCO is a more efficient method of STR enrichment when compared to other methods, as only 36 microsatellites were found from 70 positive clones (Liu, et al., 2007). Furthermore, 40 (66.67\%) STRs were imperfect in the present study, whereas 33\% were perfect and compound (Weber, 1990).

A survey of the literature confirmed these eight loci to be newly identified and most of these eight loci were perfect loci (Jarne and Lagoda, 1996). The average PIC value in this study was 0.5112 , which is almost triple that obtained in a previous study of the same species (Yang et al., 2014). Meanwhile, each value for $\mathrm{H}_{\mathrm{E}}$ was much lower than the value for $\mathrm{H}_{\mathrm{O}}$, revealing low genetic diversity of this population.

In summary, these data suggest that the germplasm resources of $A$. schlegelii are declining and future studies should aim to protect the genetic resources of $A$. schlegelii.

\section{Conflicts of interest}

The authors declare no conflict of interest.

\section{ACKNOWLEDGMENTS}

Research supported by the National Natural Science Foundation of China (\#31272668), the Program for New Century Excellent Talents in Fujian Province University, and the Foundation for Innovative Research Team of Jimei University, China (\#2010A004). 


\section{REFERENCES}

Botstein D, White RL, Skolnick M and Davis RW (1980). Construction of a genetic linkage map in man using restriction fragment length polymorphisms. Am. J. Hum. Genet. 32: 314-331.

Clarke KR and Gorley RN (2001). Primer (Plymouth Routines in Multivariate Ecological Research) v5: User Manual. Tutorial, PRIMER-E Ltd. Plymouth 91.

Dou YQ, Liang XF, Yang M, Tian CX, et al. (2015). Isolation and characterization of polymorphic EST-SSR and genomic SSR markers in spotted mandarin fish (Siniperca scherzeri Steindachne). Genet. Mol. Res. 14: 19317-19322.http:// dx.doi.org/10.4238/2015.December.29.41

Field D and Wills C (1996). Long, polymorphic microsatellites in simple organisms. Proc. Biol. Sci. 263: 209-215.http:// dx.doi.org/10.1098/rspb.1996.0033

Fushimi H (2001). Production of juvenile marine finfish for stock enhancement in Japan. Aquaculture 200: 33-53.http:// dx.doi.org/10.1016/S0044-8486(01)00693-7

Gonzalez EB, Nagasawa K and Umino T (2008). Stock enhancement program for black sea bream (Acanthopagrus schlegelii) in Hiroshima Bay: monitoring the genetic effects. Aquaculture 276: 36-43.http://dx.doi.org/10.1016/j. aquaculture.2008.02.004

Jarne P and Lagoda PJ (1996). Microsatellites, from molecules to populations and back. Trends Ecol. Evol. (Amst.) 11: 424-429.http://dx.doi.org/10.1016/0169-5347(96)10049-5

Jeong DS, Gonzalez EB, Morishima K, Arai K, et al. (2007). Parentage assignment of stocked black sea bream Acanthopagrus schlegelii in Hiroshima Bay using microsatellite DNA markers. Fish. Sci. 73: 823-830.http://dx.doi. org/10.1111/j.1444-2906.2007.01402.x

Kitada S and Kishino H (2006). Lessons learned from Japanese marine finfish stock enhancement programmes. Fish. Res. 80: 101-112.http://dx.doi.org/10.1016/j.fishres.2006.03.019

Lindberg GU and Krasyukova ZV (1969). Fishes of the Sea of Japan and the Adjacent Areas of the Sea of Okhotsk and the Yellow Sea, Part 3.

Liu YG, Liu LX, Li ZX, Gao AY, et al. (2007). Development of polymorphic microsatellite from RAPD bands of black sea bream Acanthopagrus schlegeli. Mol. Ecol. Notes 7: 1178-1180.http://dx.doi.org/10.1111/j.1471-8286.2007.01823.x

Luo XN, Yang M, Liang XF, Jin K, et al. (2015). Genetic diversity and genetic structure of consecutive breeding generations of golden mandarin fish (Siniperca scherzeri Steindachner) using microsatellite markers. Genet. Mol. Res. 14: 11348-11355.http://dx.doi.org/10.4238/2015.September.25.1

Ning YF, Li ZB, Li QH, Dai G, et al. (2015). Isolation and characterization of novel microsatellite markers for molecular genetic diversity in Siganus fuscescens. Genet. Mol. Res. 14: 89-92.http://dx.doi.org/10.4238/2015.January.15.11

Sambrook JD and Russell W (2000). Molecular cloning. 2nd edn. Cold Spring Harbor Laboratory Press, Cold Spring Harbor, New York

Shahidul Islam M and Tanaka M (2004). Impacts of pollution on coastal and marine ecosystems including coastal and marine fisheries and approach for management: a review and synthesis. Mar. Pollut. Bull. 48: 624-649.http://dx.doi. org/10.1016/j.marpolbul.2003.12.004

Van Oosterhout C, Hutchinson WF and Shipley P (2004). MICRO-CHECKER: software for identifying and correcting genotyping errors in microsatellite data. Mol. Ecol. Notes 4: 535-538.http://dx.doi.org/10.1111/j.1471$\underline{8286.2004 .00684 . x}$

Weber JL (1990). Informativeness of human (dC-dA)n.(dG-dT)n polymorphisms. Genomics 7: 524-530.http://dx.doi. org/10.1016/0888-7543(90)90195-Z

Yang Y, Cao X, Feng R, Chen S, et al. (2014). Isolation and characterization of thirteen polymorphic microsatellite loci from black porgy (Acanthopagrus schlegeli). J. Genet. 93: e97-e99.

Zane L, Bargelloni L and Patarnello T (2002). Strategies for microsatellite isolation: a review. Mol. Ecol. 11: 1-16.http:// dx.doi.org/10.1046/j.0962-1083.2001.01418.x 